\title{
Molecular carcinogenesis of hepatocellular carcinoma and intrahepatic cholangiocarcinoma: one step closer to personalized medicine?
}

\author{
Mia Kumar, Xuelian Zhao, Xin Wei Wang ${ }^{*}$
}

\begin{abstract}
Hepatocellular carcinoma (HCC) and intrahepatic cholangiocarcinoma (ICC) are the two major forms of primary liver cancers (PLC), accounting for approximately $90 \%$ and $5 \%$ respectively. The incidence of each is increasing rapidly in the western world, however our knowledge of the underlying mechanisms remains limited and the outcome, dismal. The etiologies of each vary geographically; nevertheless, chronic inflammation has been identified in more than $80 \%$ of the cases and appears to be a key mediator in altering the liver microenvironment, increasing the risk of carcinogenesis. However, since not all HCC and especially ICC cases have a recognized risk factor, there are currently two proposed models for liver carcinogenesis. The clonal evolution model demonstrates a multi-step process of tumor development from precancerous lesions to metastatic carcinoma, arising from the accumulation of genetic and epigenetic changes in a cell in the setting of chronic inflammation. While the majority of cases do occur as a consequence of chronic inflammation, most individuals with chronic infection do not develop PLC, suggesting the involvement of individual genetic and environmental factors. Further, since hepatocytes and cholangiocytes both have regenerative potential and arise from the same bi-potential progenitor cell, the more recently proposed cancer stem cell model is gaining its due attention. The integration of these models and the constant improvement in molecular profiling platforms is enabling a broader understanding of the mechanisms underlying these two devastating malignancies, perhaps moving us closer to a new world of molecularly-informed personalized medicine.
\end{abstract}

\section{Introduction}

Primary liver cancer (PLC) is the fifth most common cancer worldwide and the third most deadly, with approximately 600,000 deaths annually. Hepatocellular carcinoma (HCC), a primary malignancy of the hepatocyte, accounts for approximately $85 \%$ to $90 \%$ of all PLC, out of which $80 \%$ of HCC cases occur in either subSaharan Africa or in eastern Asia [1,2]. Cholangiocarcinoma (CCA), a malignancy of cholangiocytes in the biliary epithelium, is the second most common form and accounts for about $5 \%$ to $10 \%$ of PLC. CCA is categorized as intrahepatic or extrahepatic according to the anatomic location of the tumor. Since intrahepatic cholangiocarcinomas (ICC) usually present in small biliary ducts or ductules they are considered a PLC, compared

\footnotetext{
* Correspondence: xw3u@nih.gov

Liver Carcinogenesis Section, Laboratory of Human Carcinogenesis, Center for Cancer Research, National Cancer Institute, Bethesda, Maryland 20892,
} USA

(c) 2011 Kumar et al; licensee BioMed Central Ltd. This is an Open Access article distributed under the terms of the Creative Commons Attribution License (http://creativecommons.org/licenses/by/2.0), which permits unrestricted use, distribution, and reproduction in any medium, provided the original work is properly cited. to extrahepatic cholangiocarcinomas which are a form of biliary tract cancer. The incidence of CCA varies with regards to the two forms; however, for purposes of this review we will address ICC, which has the highest incidence in eastern Asia, particularly Thailand, with an increasing risk ratio in the western world [3-5]. The remaining PLC subtypes, which account for less than $5 \%$ of cases, are fibrolamellar HCC, hepatoblastoma, angiosarcoma, epithelioid hemangioendothelioma and hepatocellular adenoma.

Risk factors that lead to the multistep development of HCC are well known and it is established that approximately $80 \%$ of HCC cases develop in individuals suffering from chronic hepatitis $\mathrm{B}$ or $\mathrm{C}$ viral infection (HBV or $\mathrm{HCV}$ ), cirrhosis, and also those with a high exposure to aflatoxin-b1 (AFB). HCC is particularly attributed to these exposures due to the extensive oxidative stress and release of inflammatory cytokines induced by viral infection in the setting of liver inflammation. Diabetes,

\section{Biomed Central}


obesity, smoking and alcohol abuse have also been associated with the development of $\mathrm{HCC}$, but with reduced frequency [6-8]. Currently, individuals at risk for HCC are routinely screened by ultrasonography and alphafetoprotein (AFP) levels but most patients are still diagnosed with an advanced disease stage and therefore a 5-year survival for the majority of HCC patients' remains dismal $[9,10]$. Due to the high variability in AFP evaluation, affected by the specificity of the test, ethnic backgrounds and tumor size, an improvement in screening procedures is highly awaited. Furthermore, the impairment of liver function and the expression of multi-drug resistance genes render HCC treatment difficult [11]. This review discusses the mechanistic changes that occur during the development of $\mathrm{HCC}$ and the potential targets that are being investigated for new screening techniques, with the hope that this will lead to a more personalized treatment regimen to improve patient outcome.

Risk factors for ICC, on the other hand, are not so well established given that approximately $90 \%$ of ICC patients lack a recognized risk factor for the disease [12]. Furthermore, ICC cases appear to develop in otherwise healthy livers, with only $10 \%$ resulting from chronic inflammation [3]. Nevertheless, relatively strong CCA associations have been established with primary sclerosing cholangitis (PSC) [13-15], liver fluke infestations [14,16] and hepatolithiasis [3]. Other possible, but not well characterized associations may also exist with HBV or HCV infection [17-19] and alcohol consumption $[20,21]$. The molecular interactions and genomic alterations in cholangiocytes that drive the development of CCA are not clear and the absence of specific symptoms and diagnostic tests make the disease difficult to identify in premalignant stages. Currently, 5-year survival rate for ICC cases remains below 5\% [3], with the only hope for improved survival being complete resection of the tumor. This underscores the need for increased research in this field and for the development of improved diagnostic criteria and treatment options. The increased utilization of genome-wide association studies (GWAS) will be particularly useful to identify large-scale genetic variants in PLCs, particularly cholangiocarcinoma, since so little is currently understood.

As mentioned, in this review we will describe the current understanding in the molecular mechanisms, specifically the genetic, epigenetic and signaling alterations that take place, which give rise to the majority of PLC cases observed, separated by HCC and ICC. Furthermore, it is interesting to note the two models for tumorigenesis, a step-wise clonal evolution model and a cancer stem cell (CSC) model, that have arisen as a consequence of our improved understanding in this field. How these models will impact PLC cases in the clinical setting will provide for a stimulating discussion.

\section{Hepatocellular Carcinoma}

\section{Altered signaling pathways in $\mathrm{HCC}$ at the genomic and} transcriptomic levels

In a setting of chronic inflammation, the organ microenvironment experiences a variety of molecular changes that, in fact, often stem from the process and consequence of inflammation. In liver, cytokines and reactive oxygen and nitrogen species produced by inflammatory cells have been shown to mediate liver damage and induce the liver's regenerative response [22-26]. This predisposes the proliferating cell to a variety of genetic changes at the genomic and transcriptional levels.

\section{Genomic alterations}

Large-scale quantitative comparisons of HCC tumors to non-tumors by the use of comparative genomic hybridization $(\mathrm{CGH})$ arrays and loss of heterozygosity $(\mathrm{LOH})$ has revealed the occurrence of chromosomal and microsatellite instability in HCC. The most frequently deleted chromosomes arms are 1p, 4q, 6q, 8p, 9p, 13q, 16p, 16q and $17 \mathrm{p}$ and regional gains are most often observed in $1 q, 6 p, 8 q$ and $17 q[27,28]$, which, in general corresponds to autosome arms that contain allelic deletions identified by LOH: 1p, 1q, 4q, 5q, 6q, 8p, 9p, 13q, 16p, $16 q$ and $17 p[27,29,30]$. Unrelated to tumor size, individual HCCs can represent multiple allelic deletions and chromosomal gains and losses, which can accumulate during successive cell proliferation events and results in a heterogeneous mixture of genomic aberrations [31]. The heterogeneity of tumors can help to identify tumor origin and due to the sensitivity of CGH and SNP arrays, genomic alterations can be used as fingerprints to identify whether a tumor is a recurrent event or a second primary tumor [32,33]. The frequent loss of chromosome regions observed by LOH and SNP arrays has revealed the concomitant loss or mutation of tumor suppressor genes such as TP53 (p53), retinoblastoma $R B 1(\mathrm{Rb})[34,35], C D K N 2 A\left(\mathrm{p} 16^{\mathrm{INK} 4 \mathrm{~A}}\right)[29,36]$ and insulin-like growth factor-2 receptor $I G F-2 R[37,38]$, which are strongly associated with carcinogenetic signaling pathways $[29,34,39,40]$. Gain of function mutations have also been observed in HCC, for example mutations in CTNNBI ( $\beta$-catenin), which results in the deregulation of similar signaling pathways in $\mathrm{HCC}[41,42]$.

TP53 gene encodes the p53 protein which plays a pivotal role in the DNA-damage response network, including cell cycle arrest, apoptosis, DNA repair and cellular senescence. Therefore, it is not surprising that TP53 loss of function mutations or allelic deletions in chromosome $17 \mathrm{p}$ are commonly associated with human carcinogenesis [43], and depending on the extent of damage, p53 can either regulate the production of antioxidant genes to initiate DNA repair, or induce apoptosis through the activation of pro-oxidant genes[29]. AFB1 is a particular mutagen of TP53, causing G:C 
to $\mathrm{T}$ :A transversions at the third base in codon 249 (converting arginine to serine), and the rate of TP53 R249S mutation may be accelerated in the presence of viral infection $[44,45]$. HBV encodes a viral protein, $\mathrm{HBx}$, which can specifically bind to p53 and suppress p53-induced apoptosis [46]. Strong associations have been observed between TP53 R249S mutation levels and HCC risk, especially with respect to primary tumor development and also the interval between surgical resection and recurrence $[47,48]$. A recent study has linked this p53 hotspot mutation to HCC with aggressive tumors, poor prognosis and an acquisition of stem cell-like traits[49], which is not unexpected since a separate study has shown that TP53 mutations have the ability to reprogram terminally differentiated cells into pluripotent stem cells[50].

\section{Transcriptomic alterations: the deregulation of signaling} pathways in HCC

Structural genomic mutations and epigenetic changes may lead to altered gene expression patterns that significantly affect the signal transduction pathways in HCC and the variability in pathway expressed may allude to the cellular origin of HCC. A selection of the relevant signaling pathways altered in $\mathrm{HCC}$ is discussed here (Figure 1).

TGF- $\boldsymbol{\beta}$ is an inflammatory cytokine implicated in an array of functions such as cell growth, differentiation, migration, apoptosis, adhesion, survival and immunity [51]. IGF-2R, a tumor suppressor gene, promotes the degradation of mitogen IGF-2 and also the simultaneous activation of transforming growth factor- $\beta$ (TGF- $\beta$ ) signaling, thereby halting cell proliferation and carcinogenesis [52]. Inflammation and subsequent genomic mutations in IGF-2R result in IGF-2 over-expression and a reduction in the inhibitory effects of TGF- $\beta$ signaling, a feature commonly observed early in the development of HCC [53,54]. Immunohistochemical analysis of HCC has also revealed a disruption of TGF- $\beta$ signaling coinciding with an increase in the expression of stem cell markers and the activation of interleukin- 6 (IL-6). This indicates a link between IL-6, a major stem cell signaling pathway and the disruption of TGF- $\beta$ signaling, resulting in CSC driven $\mathrm{HCC}[55]$.

Interestingly, IL-6 activation is a frequent event in HCC. Recent studies indicate that gain of function mutations of glycoprotein-130 (gp130), a co-receptor of IL-6, is associated with a marked activation of IL-6 in inflammatory hepatocellular adenomas[56]. Noticeably, rare gp130 alterations are always accompanied by $\beta$-catenin activating mutations in $\mathrm{HCC}$, suggesting that these two signaling pathways are converged to contribute to hepatocarcinogenesis. Additional details about $\beta$-catenin involvement in HCC are described below.
Wnt/ $\boldsymbol{\beta}$-catenin. This developmental pathway is commonly known for its fundamental role in embryogenesis, which aids the cell in differentiation, proliferation and apoptosis. In the absence of Wnt signaling, cytoplasmic $\beta$-catenin complexes with the tumor suppressors: adenomatosis polyposis coli (APC) and Axin1, as well as the

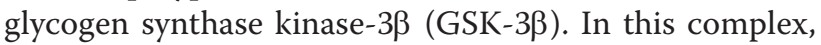
GSK-3 $\beta$ phosphorylates $\beta$-catenin, targeting it for ubiquitiniation and subsequent degradation. In the event that Wnt signaling receptors are engaged, conformational changes in the Axin complex cause the release of $\beta$-catenin, which then localizes to the nucleus and activates the transcription of Myc, cyclin D1 and COX2 amongst others [57-59]. In HCC, our studies and a number of other transcriptomic and proteomic studies have indicated an increase in Wnt signaling, possibly as a result of an accumulation of Axin1 mutations at sites that bind $\beta$-catenin and/or CTNNB1 mutations along sites marked for phosphorylation by GSK-3 $\beta[60,61]$. It is hypothesized that an increase in signaling from the Wnt pathway is necessary to maintain "stemness" in HCC, characterized by cell proliferation and immortality, an event that may be representative of CSCs $[60,62]$.

Myc is a potent oncogene, which appears to be constitutively up-regulated in many human cancers, representing a phenomenon of "oncogene addiction." Though about $30 \%$ of HCC cases show an up-regulation of Myc because of the Wnt/ $\beta$-catenin pathway[63], its increased expression in HCC is also attributable to the activation of its locus through chromosome amplification [64] One possible mechanism by which Myc contributes to hepatocarcinogenesis is through the induction of telomerase, which also appears to be active during HCC development[65], thereby bypassing cellular senescence. Moreover, the up-regulation of Myc in a variety of tumors has also been associated with deregulated microRNA (miRNA) expression in many human malignancies [66], which as discussed in the next section, have a significant impact on tumorigenesis and progression. On the other hand, the inactivation of Myc in HCC causes a subpopulation of cells to differentiate while the rest remain dormant, giving rise to a phenotypically diverse tumor population and possibly the origin of CSCs [67].

PI3K/PTEN/Akt. The activation of the Akt pathway is mediated by either an activated tyrosine kinase receptor, or more rarely the constitutive activation of PI3K or the loss of phosphatase and tensin homolog (PTEN). PTEN is a tumor suppressor gene and the PTEN protein functions as a negative regulator of Akt. The loss of PTEN expression via a loss of heterozygosity in chromosome $10 \mathrm{q}$ along with an activation of Akt has been reported in $40 \%-60 \%$ of $\mathrm{HCC}$ cases $[68,69]$. Since Akt is involved in a number of biological processes, such as 


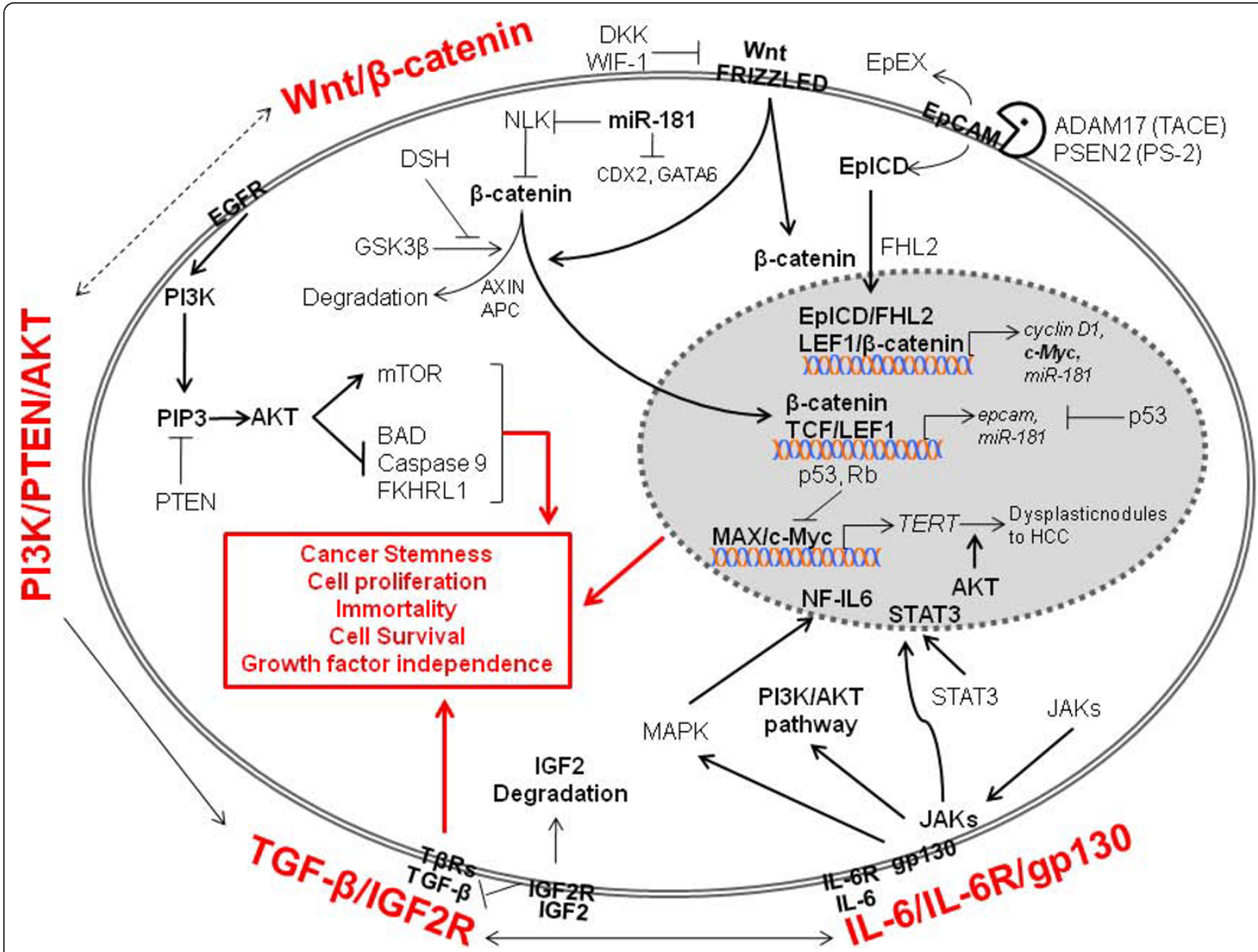

Figure 1 Signaling Pathways Altered in Hepatic Cancer Stem Cells. Wnt/ $\beta$-catenin, PI3K/PTEN/AKT, TGF- $\beta /$ /GF-2R and IL-6/IL-6R/gp130 signaling pathways have been shown to be activated in HCC. Activation of the Wnt pathway results in $\beta$-catenin accumulation in the cytosol and translocation into the nucleus, where $\beta$-catenin forms two major protein-DNA complexes. 1) $\beta$-catenin/TCF/LEF is a classic complex of Wnt/ $\beta$-catenin pathway that mediates Wnt target genes expression, e.g. EpCAM and miR-181; 2) EpICD/FHL2/ $\beta$-catenin/LEF1-DNA complex represents a cross-talk of Wnt/ $\beta$-catenin with EpCAM signaling pathway [133]. Cleavage of EpCAM by TACE and PS-2 releases EpICD into cytosol which in turn translocates into the nuclues with $\beta$-catenin and FHL2, where EpICD/FHL2/ $\beta$-catenin forms protein-DNA complex with LEF1and regulates EpCAM target genes expression, e.g. cyclin D1, c-Myc andd miR-181. AKT is activated by two phosphorylation sitess Thr308 and Ser473. Phosphorylation of Thr308 is promoted by PI3K and suppressed by PTEN. Activated AKT induces cell survival through the suppressive phosphorylation of BAD and Caspase 9, two apoptosis mediators in unphophorylated status. AKT also acts as a cell cycle progression regulator through activating the mTOR pathway [134]. Two oncogenic pathways PI3K/PTEN/AKT and Wnt/ $\beta$-catenin may be interconnected to promote stemness and carcinogenesis. Loss of IGF-2R impacts cell proliferation by accumulating IGF-2 mitogen and activation of TGF- $\beta$ signaling.

cell survival, cell growth, apoptosis and differentiation, its deregulation has been implicated in many human cancers. Though the role of Akt in HCC is not confirmed, its activation is interestingly linked to more aggressive tumors in HCC [70] and an activation of $\beta$ catenin signaling in intestinal stem cells, suggesting that the two oncogenic pathways: PI3K/PTEN/Akt and Wnt/ $\beta$-catenin may be interconnected to promote stemness and carcinogenesis [71].

\section{Aberrant expression of miRNAs in HCC}

In recent years, the aberrant expression of miRNAs has been implicated in a wide variety of human cancers.
miRNAs are a class of small non-coding RNAs that play a critical role in biological processes of cell development and differentiation and the deregulated expression of miRNAs in HCC has revealed their functional involvement in HCC carcinogenesis and progression [72].

For example, in HCC cases, gene expression profiling reveals that an up-regulation of miR-181 is associated with increased signaling in $\mathrm{Wnt} / \beta$-catenin pathways and conversely, siRNA mediated inhibition of the TGF- $\beta$ pathway indicates a decreased expression of miR-181 $[73,74]$. Moreover, loss of let-7g expression is associated with HCC metastasis [75]. miR-26 expression has been 
found to be associated with $\mathrm{HCC}$ gender disparity and silencing of miR-26 in tumor cells is linked to a subtype of HCC with an activated inflammatory pathway and a favorable response to interferon therapy [76]. In addition, increased expression of miR-21 has been associated with loss of heterozygosity at the PTEN locus, consequently activating the Akt pathway and promoting tumorigenesis $[77,78]$. Similarly, miRNAs associated with the cell cycle regulation and apoptosis inhibition in HCC have also been identified [79].

A study in our lab has revealed a 20-miRNA-based signature that is associated with HCC venous metastasis, details of which are expanded upon at the end of this article. This signature provides promise to a future of personalized medicine since it can be used clinically to identify patients with early-stage disease or metastases and can even be used to predict survival and recurrence [80].

\section{Epigenetic modifications may improve the early detection of HCC cases}

In the last decade there has been increasing evidence to support the occurrence of aberrant DNA methylation patterns in human HCC [27]. Therefore, in addition to genetic mechanisms of deletions or mutations, epigenetic changes can increase or decrease gene expression via regulating DNA methylation. DNA methylation in the mammalian genome is found at the cytosine residues of $\mathrm{CpG}$ dinucleotides, often associated with promoter-related CpG islands. Though methylation is imperative for normal development and differentiation, aberrant hypomethylation in HCC and many human cancers can lead to the expression of oncogenes [81], or, similarly, hypermethylation can lead to the silencing of tumor-suppressor genes [82]. In HCC, an increased expression of DNA methyltransferases (DNMTs), enzymes which catalyze epigenetic alterations, occurs early in the development of tumorigenesis. The frequency of aberrant DNA methylation increases from precancerous lesions to dysplastic nodules and finally HCC, signifying their important role in tumor progression [83]. For instance, the tumor suppressor genes: RB1 [84] and CDKN2A [36] have been shown to be hypermethylated in $\mathrm{HCC}$, leading to uncontrolled cell proliferation. Likewise, PTEN promoter methylation has also been reported in HCC, which allows the progression of the PI3K/PTEN/Akt pathway [85].

Epigenetic changes in $\mathrm{HCC}$ have also been reported at the miRNA level. For example, the deregulation of miR1 due to hypermethylation in HCC was reversed with 5 -azacytidine, resulting in decreased cell proliferation and increased apoptosis [86]. A similar association has been observed with miR-124 and also miR-203, amongst others, in HCC [87].
Since distinct methylation signatures of tumor suppressor genes have been observed in high-risk subjects up to 9 years before clinical diagnosis, DNA methylation profiling may provide a unique tool to reliably predict cancer status. Apart from their potential as a diagnostic platform though, further understanding of methylation patterns in HCC may provide them useful in determining recurrence and survival, as well [88].

\section{Transcription profiles and the identification of HCC tumor subtypes}

Recent breakthroughs in technology have provided comprehensive genetic and transcriptomic profiling platforms that are successfully used in identifying tumor subtypes and predicting patient outcome and survival. In addition to classifying tumor aggressiveness, high-throughput molecular profiling systems are also useful in determining how the tumor will respond to treatment.

Global gene expression analysis of HCC has revealed two distinctive subclasses of human HCC that are highly associated with patient survival [89]. The low survival subclass was marked by increased expression of cell proliferation and antiapoptotic genes, such as PCNA and PTMA, respectively. Moreover, the poor survival subgroup also expressed a higher number of genes related to ubiquitination and histone modification, namely UBE2D1 and HRMT1L2, respectively.

Additional transcriptome analysis of $\mathrm{HCC}$ samples has classified HCC into 6 subgroups associated with clinical and genetic characteristics, which further identify two tumor groups linked to chromosome instability (Groups 1-3) or stability (Groups 4-6) [90]. The first group was linked to low copy number HBV infection, particularly in Africa, increased Axin 1 mutations, absence of TP53 mutations and possessed an over expression of imprinted genes. The second group was linked to high copy number HBV infection, many regions of $\mathrm{LOH}$, and TP53 and Axin1 gene mutations. These first two groups are the only ones that employed the Akt biological pathway and appeared most genetically distinct from the remaining subgroups. Groups 5 and 6 were also substantially different since they were easily classified based on the abundance of CTNNB1 mutations (near 100\%) and the high level of Wnt pathway activation.

Recently, our lab identified another 2 HCC subtypes based on their expression of a hepatic stem cell marker, epithelial cell adhesion molecule (EpCAM) and EpCAMcoexpressed genes[91]. EpCAM-positive HCC correlated with increased Wnt pathway activation, cytokeratin 19 and c-Kit, which are all known markers of progenitor cells. On the other hand, EpCAM-negative HCC resembled gene expression patterns of mature hepatocytes. Further analysis based on AFP levels allowed these two subgroups to be further divided into 4 subtypes with 
the ability to predict prognosis. Based on this classification, poor clinical outcome is correlated with AFP expression and good prognosis was only associated with $\mathrm{EpCAM}^{+} \mathrm{AFP}^{-}$cases.

Insights into tumor response to treatment are being elucidated and our lab recently identified the importance of miR-26a and miR-26b in survival and response to interferon therapy [76]. Compared to paired noncancerous tissue, HCC samples had decreased miR-26 expression correlating with an increase in nuclear factor $\kappa \mathrm{B}(\mathrm{NF}-\kappa \mathrm{B})$ and IL-6 signaling. Furthermore, clinical data revealed that those patients with low miR-26 expression had a better response to adjuvant interferon therapy with interferon alpha than those with high miR26 expression.

Taken together, transcriptional profiling platforms are beginning to provide a vast amount of useful information that can be synthesized to identify HCC subtypes, patient outcome, and survival and treatment options. Still, new insights into the potential cellular origin of $\mathrm{HCC}$ and its activated molecular pathways are necessary to improve targeted therapy.

\section{Two models of hepatocarcinogenesis may complement one another}

The longstanding clonal evolution model for HCC development is a multistep event, which may take 30 years to unfold. As described earlier, the various etiological factors, particularly inflammation and viral hepatitis, appear to contribute significantly to approximately $90 \%$ of HCC cases by creating phenotypically altered hepatocytes. The stepwise progression from altered hepatocytes to dysplastic nodules, or precancerous lesion, occurs as a consequence of chronic inflammation and genomic alterations, which commonly precede HCC $[27,39,92]$. Therefore, the accumulation of genetic and epigenetic changes, such as the loss of tumor suppressor genes and the gain of an oncogene, gives rise to a mass of primary tumor cells that are considered monoclonal in origin[92,93]. Though from a scientific standpoint this model has vastly improved our understanding of the various genetic and signaling events underlying HCC development, it is unfortunate that these findings have not been translated into better treatment options as liver resection and transplantation still remain the best choice and only benefits a small population.

A more recently proposed stem cell model for HCC tumorigenesis may provide a more personalized approach to address diagnostic and therapeutic strategies in the clinic (Figure 2). This model hypothesizes that HCC could be derived from progenitor cells or de-differentiated transformed cells; based on the observation that embryonic stem cells (ESC) and CSCs behave similarly. This would be able to explain the heterogeneous nature of HCC morphology, clinical behavior, and molecular profiles $[60,94]$. Since the liver is an organ with regenerative capacity, it has bi-potential progenitor cells that can give rise to hepatocytes or chloangiocytes, which could possibly develop into HCC or ICC, respectively [95,96]. Furthermore, cases with a mixed morphology have also been identified. Based on the expression of EpCAM, a substantial number of HCC cases consist of progenitor cells and their heterogeneous progeny with a capacity to self-renew and limitlessly divide $[60,91,94]$. This relatively new hypothesis is not intended to be contradictory to the step-wise model, but merely complementary in explaining the origin of a more comprehensive group of HCC cases and the arising issues in diagnosis and treatment.

For example, mature hepatocytes, cholangiocytes or bi-potential progenitor cells that acquire mutations through random genetic or epigenetic events can introduce a genetic imbalance in the primary tissue, resulting in the de-differentiation of mature cells and the loss of cell cycle control and/or the ability to continuously self renew. Depending on the extent of genetic alterations, the tumor cells may remain benign or develop and metastasize. Therefore, events initiated by the multistep carcinogenesis model can also result in heterogeneous tumors with stem cell capability and the potential to be more aggressive.

\section{Intrahepatic Cholangiocarcinoma}

An increasing global incidence of ICC [5] has recently hastened research in this field to understand the mechanisms underlying pathogenesis of this dreadful disease. Reviewing the mechanisms of ICC indicates that similarities can be drawn between ICC and HCC, which may improve the prospects of this disease in a clinical setting. Particularly, the tumorigenesis models proposed for ICC development are remarkably similar to those for HCC. Furthermore, several histopathologic and gene expression profiling studies have shown PLC tumors that exhibit a combination of HCC and CCA traits, suggesting an overlap between these tumor types. A subtype of tumors showing combined characteristics of hepatocellular-cholangiocarcinoma ( $\mathrm{CHC}$ ) have been reported and proposed to develop from the bi-potential liver stem cells [97]. Even more recently, a new subtype - cholangiocarcinoma-like HCC (CLHCC) -was discovered and characterized as HCC expressing CCA-like traits. The heterogeneity observed between all 4 tumor subtypes could be indicative of their cellular origins from different developmental stages and may also represent a novel way to approach targeted therapy in CCA and HCC [98].

Comparable to $\mathrm{HCC}$, ICC most commonly arises in the setting of chronic inflammation, often within bile ducts [99] and likely due to liver fluke Opisthorchis viverrini infestation [100], PSC[101] or hepatolithiasis 


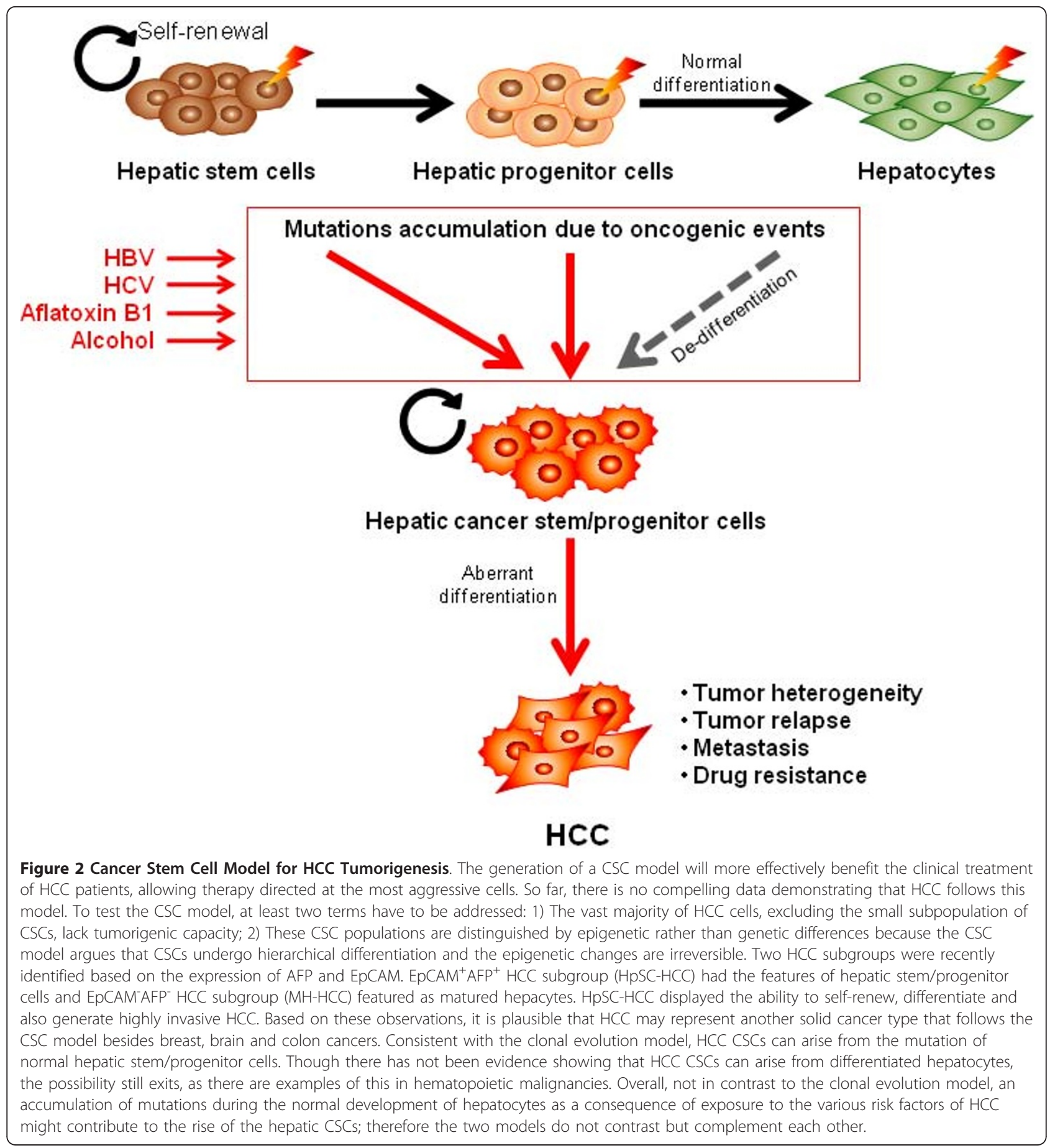

[102]. The continuous production of inflammatory cytokines and the induction of inducible nitric oxide synthase (iNOS) lead to oxidative and nitrosative DNA damage [100], increased cell turnover and inhibition of DNA repair mechanisms [103]. In the stepwise model, an accumulation of inflammatory-mediated genetic and epigenetic alterations has been proposed to lead to the successive development of ICC from biliary epithelial cells to biliary dysplastic lesions and eventually cancer [104].

There is growing evidence supporting a hepatic stem cell model of cholangiocarcinoma $[96,105,106]$. Interestingly, the same bi-phasic progenitor cell can give rise to hepatocytes and cholangiocytes, as mentioned earlier, and each of these cells has longevity and repopulating potential [107]. Therefore, in the setting of chronic 
inflammation, a tumor could arise from the clonal evolution of either mature cholangiocytes which de-differentiate, or progenitor cells; allowing a combination of the two proposals. Furthermore, depending on the degree of differentiation achieved before maturation arrest, one can observe a heterogeneous tumor with a range of neoplastic phenotypes [107]. One author explains that the dysplastic nodules observed during carcinogenesis may be adaptive non-oncogenic responses to carcinogenic substances, rather than a multistep accumulation of genomic alterations [105].

\section{Genetic alterations that manifest in ICC Genomic alterations}

In a study aimed at distinguishing chromosomal changes between HCC and ICC, CGH analysis reveals the frequency of chromosomal losses in ICC is higher [53]. Short segments of chromosomes 1p [108], 3p, 6q and 9q $[28,108]$ are commonly deleted in ICC, with a frequency of at least 55\%, whereas the frequency of such events in HCC are usually less than 40\% [28]. Commonly amplified regions in ICC are in segments of $1 \mathrm{q}$, $7 q, 7 p$ and $8 q[28,108]$, with an amplification frequency of at least $30 \%$. Losses in regions of $6 q$ and $3 p$ appear to be highly characteristic of cholangiocarcinoma, but overall the high frequency of gains and losses appears to carry a poor prognostic value [28]. Further studies to detect the loss of tumor suppressor genes during a consistent $\mathrm{LOH}$ have indicated a high rate of allelic losses at $5 \mathrm{q}$ and $17 \mathrm{p}[109,110]$. $\mathrm{LOH}$ has been observed in other chromosomal regions, but to a lesser extent, and may represent random error. HCC and ICC share similar allelic losses in the $5 \mathrm{q}$ and $17 \mathrm{p}$ regions, allowing some to propose that these two tumors arise from the same CSC and therefore may share similar genetic changes during tumorigenesis [105,110]. Persistent structural genomic changes in these cells have been associated with a variety of mutations, conferring a loss in tumor suppression and the amplification of oncongenic pathways.

TP53 mutations in ICC are common and their frequency ranges from $20-80 \%$ depending on the geographic region $[111,112]$. Though the deregulation of p53 in ICC is similar to HCC, as there is a loss of cell cycle control and a decrease in apoptotic events, the deregulation in ICC is sometimes more associated with an accumulation of inactive wild-type p53 and its inhibitor $\mathrm{mdm}-2$, rather than a loss of function mutation $[113,114]$. This renders the p53 regulatory pathway nonfunctional and supports the notion that either TP53 mutations or an alteration to the p53 pathway may be critical to the development of ICC $[115,116]$. The regulation of cell cycle entry by p53 involves, amongst others, the $\mathrm{p} 21^{\mathrm{WAF} 1 / \mathrm{Cip} 1}$ protein, which binds to the cell division kinase (CDK) 4:cyclin D complex and prevents the phosphorylation of $\mathrm{Rb}$ protein. The CDK4:cyclin $\mathrm{D}$ complex is also influenced by the $\mathrm{p} 16^{\mathrm{INK} 4 \mathrm{~A}}$ inhibitory protein[117], which coincidentally is altered by $\mathrm{LOH}$ and/or promoter hypermethylation in $25 \%-83 \%$ of resected cholangiocarcinoma specimens [118,119].

K-ras mutations occurring at codon 12 are often observed in ICC, involving either a glycine to aspartic acid or a glycine to cystine transition $[111,115]$. Less frequent mutations have been observed in codon 13 (second nucleotide) and codon 61 (third nucleotide) [120]. $\mathrm{K}$-ras mutations corresponding to over expression are observed early in carcinogenesis, which suggests an important role in ICC development. Furthermore, K-ras has been implicated in aggressive ICC downstream of the biliary tree with increased expression levels in metastatic lymph nodes [121]; therefore K-ras expression correlates to poor prognosis [122].

Transcriptomic alterations: Enhanced proliferation signaling in ICC

The inactivation of tumor suppressor genes and the concordant amplification of proto-oncogenes, such as TP53 and K-ras, respectively, play a significant role in altering the signaling network and promoting tumorigenesis. The exact mechanism by which these pathways are affected is currently unknown, especially since most of the mechanisms have only been observed in ICC cell lines. Since in vivo studies in animal models poorly correlate with clinical outcome, the need to recreate an ICC model to better understand this disease is underscored. Despite this lack of conclusive data, several studies have identified a selection of important mechanisms contributing to the development of ICC, emphasizing the role of TGF- $\beta$, IL- 6 , STAT-3, COX-2 and $\beta$-catenin $[99,123]$. Because of the similarities already observed in the etiology and structural changes between HCC and ICC, and since some pathways most likely overlap, one may try to infer the mechanisms underlying HCC on ICC and compare this with gene expression arrays to arrive at a more functional understanding of molecular pathogenesis in ICC.

\section{Transcriptomic alterations: the recent identification of miRNAs in ICC}

Just as in HCC, the altered expression of miRNAs in ICC has been reported to contribute to tumor growth. Malignant cholangiocytes appear to be marked by an over-expression of miR-21, miR-141 and miR-200b [124]. The increased expression of miR-21 and miR200b has been linked to increased cellular proliferation, mediated by a down-regulation of PTEN and ZFHX1B tumor suppressors, respectively [78,124]. In addition, the decrease in miR-29b has been linked to the increased expression of MCL-1, an anti-apoptotic protein, resulting in decreased apoptosis [125]. Though the network of 
miRNA involvement is far greater in $\mathrm{HCC}$, the study of miRNAs in ICC is likely to lead to novel diagnostic and prognostic methods once their function is confirmed.

\section{Future Perspectives}

Currently, surgery such as liver resection remains the best treatment option for early HCC and ICC but tumor recurrence is still predominant in about $80 \%$ of $\mathrm{HCC}$ cases [126] and may be higher in ICC cases [127]. To make matters worse, effective treatment is limited for advanced stage carcinoma, which emphasizes the need to improve our understanding of primary liver cancers and consequently help improve patient diagnosis during the early stage. Intervention early in the process will improve treatment and prognosis, which may be conferred by an attempt at personalized medicine.

Individual genetic background has been suggested to contribute to HCC risk, given that only a fraction of patients with chronic liver disease or PSC actually develop HCC or ICC, respectively, even though greater than $50 \%$ of cases occur in the setting of inflammation. For this reason, the identification of genetic susceptibility loci and new biomarkers are essential to improving diagnosis and treatment outcome, and GWAS studies in liver cancer are highly necessitated.

The hypothesized CSC model for the development of HCC and ICC, and the molecular pathways, such as the Wnt/ $\beta$-catenin pathway and miR- 181 , provide valuable information about tumor growth and invasiveness. Since recently, the role of EpCAM in maintaining a stem cell phenotype in HCC and ICC is being elucidated but our studies, as well as others provide evidence for its role in the promotion of proliferation, migration and invasion potential in cells with activated Wnt $/ \beta$-catenin signaling $[60,91,128]$. Therefore, $\beta$-catenin may be a novel target in the prevention of carcinogenesis [57], highlighting the importance of molecular profiling to characterize the population of cells and their distinct molecular pathways [60].

The role of miRNA signatures has recently been elucidated through the examination of miRNA expression profiles of samples from two different subtypes in HCC, indicating miRNA profiling can be used to indicate tumor origin and aggressiveness. In these studies $[60,91,129]$, the two subtypes are hepatic stem cell like $\mathrm{HCC}\left(\mathrm{HpSC}-\mathrm{HCC}\right.$; $\left.\mathrm{EpCAM}^{+} \mathrm{AFP}^{+}\right)$and mature hepatocyte like HCC (MH-HCC; EpCAM $\left.{ }^{-} \mathrm{AFP}^{-}\right)$, where HpSCHCC cells are hepatic CSCs with the ability to selfrenew, differentiate and initiate aggressive tumors in vivo [60]. Coincidentally, among HpSC-HCC tissues, miR-181 is found to be up-regulated and functions in promoting stemness by targeting hepatic transcriptional regulators of differentiation, such as CDX2 and GATA6, and nemo-like kinase (NLK), an inhibitor of $\mathrm{Wnt} / \beta$ catenin signaling [73].
The exciting identification of miRNA signatures unique to HCC offers new platforms for cancer diagnosis and prognosis. For instance, in addition to the 20miRNA-based signature described above that is able to differentiate between CSC-like and mature hepatocytelike HCC tumors, there are additional miRNAs that can help differentiate between benign and malignant tumors, or between alcohol induced or HCV induced HCC [130]. Prognostic miRNA markers of HCC also exist, and in fact they are specific enough to help with determining metastasis [80], recurrence [131] and survival $[75,76,80]$, independently.

Studies have also indicated the therapeutic potential of miRNAs, particularly with the observance that anti-miR181 can reduce tumorigenicity in mice with hepatic CSCs, cells that are otherwise resistant to chemotherapy with 5Fluorouracil (5-FU) [60]. Along with others, our studies indicate that miR-26 functionally acts as a tumor suppressor by inhibiting cell proliferation, and a low miR-26 expression is associated with poor prognosis [76]. miR-26 expression is significantly down-regulated in HCC, but gene therapy with the delivery of miR-26 to hepatocytes considerably blocks Myc-induced HCC [76,132]. Furthermore, studies in our lab on miR-26, NF- $\kappa$ B and IL-6 have revealed the potential of miRNA expression profiles in the stratification of patients for interferon therapy [76].

\section{Conclusion}

The studies of molecular mechanisms involved in the progression to HCC have been investigated at length, and they have helped infer testable hypotheses in ICC. Advances in molecular profiling studies using DNAmicroarray based gene-expression profiling have provided increased awareness about the regulatory networks altered in human HCC and have also provided useful gene expression-based signatures that can distinguish tumor subtypes, assist clinical staging and predict patient outcomes. Since molecular profiling is proving to be an efficient way to gain insight into the molecular mechanisms underlying carcinogenesis, these techniques should also be employed more extensively in ICC so that we can obtain a more inclusive picture of regulatory elements in pathogenesis.

Advances in the specificity and sensitivity of molecular profiling platforms including expression analysis and comparative genomics with the additional incorporation of PLC databases and bioinformatics tools, we are approaching a new era for understanding the heterogeneity of HCC and ICC tumors. Such integrated platforms are enabling our improved understanding of the etiology, tumor microenvironment and the carcinogenesis of these two devastating diseases, which we hope to integrate with a personalized approach in improving the clinical outcome of these cases. 


\section{Abbreviations}

5-FU: 5-Fluorouracil; AFB: aflatoxin B1; AF: alpha-fetoprotein; CCA: cholangiocarcinoma; CDK: cell division kinase; CGH: comparative genomic hybridization; CSC: cancer stem cells; DNMT: DNA methyltransferases; EpCAM: epithelial cell adhesion molecule; GWAS: genome-wide association studies; HBV: hepatitis B virus; HCC: hepatocellular carcinoma; HCV: hepatitis b virus; HpSC-HCC: hepatic stem cell like HCC; ICC: intrahepatic cholangiocarcinoma; LOH: loss of heterozygosity; MH-HCC: mature hepatocyte like HCC; PLC: primary liver cancer; PSC: primary sclerosing cholangitis; SNP: single neucleotide polymorphism.

\section{Acknowledgements \& Funding}

We would like to thank Junfang Ji for her critical review of this manuscript and helpful suggestions and Karen Yarrick for her bibliographical assistance. This work was supported by the Intramural Research Program of the Center for Cancer Research, the National Cancer Institute (Z01 BC 010313 and Z01 BC 010876).

\section{Authors' contributions}

MRK drafted the manuscript, XZ designed the figures and XWW contributed his ideas and helped edit the paper. All authors participated equally in the design and development of this review and all authors read and approve the final manuscript.

\section{Competing interests}

The authors declare that they have no competing interests.

Received: 22 December 2010 Accepted: 24 January 2011

Published: 24 January 2011

\section{References}

1. El-Serag HB, Mason AC: Rising incidence of hepatocellular carcinoma in the United States. N Engl J Med 1999, 340:745-750.

2. Parkin DM, Bray F, Ferlay J, Pisani P: Global cancer statistics, 2002. CA Cancer Clin 2005, 55:74-108.

3. Shaib Y, El-Serag HB: The epidemiology of cholangiocarcinoma. Semin Liver Dis 2004, 24:115-125.

4. Shaib YH, Davila JA, McGlynn K, El Serag HB: Rising incidence of intrahepatic cholangiocarcinoma in the United States: a true increase? J Hepatol 2004, 40:472-477.

5. Patel $\mathrm{T}$ : Worldwide trends in mortality from biliary tract malignancies. BMC Cancer 2002, 2:10.

6. Budhu A, Wang XW: The role of cytokines in hepatocellular carcinoma. J Leukoc Biol 2006, 80:1197-1213.

7. Tardif $K D$, Waris $G$, Siddiqui $A$ : Hepatitis $C$ virus, ER stress, and oxidative stress. Trends Microbiol 2005, 13:159-163.

8. Bosch FX, Ribes J, Borras J: Epidemiology of primary liver cancer. Semin Liver Dis 1999, 19:271-285.

9. Carr Bl, Flickinger JC, Lotze MT: Hepatobiliary Cancers: Cancer of the Liver. In Cancer Principles \& Practice of Oncology.. 5 edition. Edited by: DeVita Jr VT, Hellman S. Rosenberg SA. Philadelphia: Lippincott-Raven; 1997:1087-1114.

10. Taketa K: Alpha-fetoprotein: reevaluation in hepatology. Hepatology 1990, 12:1420-1432.

11. Kato A, Miyazaki M, Ambiru S, Yoshitomi H, Ito H, Nakagawa K, Shimizu H, Yokosuka O, Nakajima N: Multidrug resistance gene (MDR-1) expression as a useful prognostic factor in patients with human hepatocellular carcinoma after surgical resection. J Surg Oncol 2001, 78:110-115.

12. Lazaridis KN, Gores GJ: Cholangiocarcinoma. Gastroenterology 2005, 128:1655-1667.

13. Kornfeld D, Ekbom A, Ihre T: Survival and risk of cholangiocarcinoma in patients with primary sclerosing cholangitis. A population-based study. Scand J Gastroenterol 1997, 32:1042-1045.

14. Thamavit W, Kongkanuntn R, Tiwawech D, Moore MA: Level of Opisthorchis infestation and carcinogen dose-dependence of cholangiocarcinoma induction in Syrian golden hamsters. Virchows Arch B Cell Pathol Ind Mol Pathol 1987, 54:52-58.

15. Burak K, Angulo P, Pasha TM, Egan K, Petz J, Lindor KD: Incidence and risk factors for cholangiocarcinoma in primary sclerosing cholangitis. Am J Gastroenterol 2004, 99:523-526.
16. Parkin DM, Srivatanakul P, Khlat M, Chenvidhya D, Chotiwan P, Insiripong $S$, L'Abbe KA, Wild CP: Liver cancer in Thailand. I. A case-control study of cholangiocarcinoma. Int J Cancer 1991, 48:323-328.

17. Kobayashi M, Ikeda K, Saitoh S, Suzuki F, Tsubota A, Suzuki Y, Arase Y, Murashima N, Chayama K, Kumada H: Incidence of primary cholangiocellular carcinoma of the liver in japanese patients with hepatitis C virus-related cirrhosis. Cancer 2000, 88:2471-2477.

18. Sorensen HT, Friis $S$, Olsen JH, Thulstrup AM, Mellemkjaer L, Linet M, Trichopoulos D, Vilstrup H, Olsen J: Risk of liver and other types of cancer in patients with cirrhosis: a nationwide cohort study in Denmark. Hepatology 1998, 28:921-925.

19. Donato F, Gelatti U, Tagger A, Favret M, Ribero ML, Callea F, Martelli C, Savio A, Trevisi P, Nardi G: Intrahepatic cholangiocarcinoma and hepatitis $C$ and $B$ virus infection, alcohol intake, and hepatolithiasis: a casecontrol study in Italy. Cancer Causes Control 2001, 12:959-964.

20. Bergquist A, Glaumann H, Persson B, Broome U: Risk factors and clinical presentation of hepatobiliary carcinoma in patients with primary sclerosing cholangitis: a case-control study. Hepatology 1998, 27:311-316.

21. Chalasani N, Baluyut A, Ismail A, Zaman A, Sood G, Ghalib R, McCashland TM, Reddy KR, Zervos X, Anbari MA, et al: Cholangiocarcinoma in patients with primary sclerosing cholangitis: a multicenter casecontrol study. Hepatology 2000, 31:7-11.

22. Hussain SP, Hofseth L, Harris CC: Radical causes of cancer. Nat Rev Cancer 2003, 3:276-285

23. Bhogal RH, Curbishley SM, Weston CJ, Adams DH, Afford SC: Reactive oxygen species mediate human hepatocyte injury during hypoxia/ reoxygenation. Liver Transpl 2010, 16:1303-1313.

24. Maki A, Kono H, Gupta M, Asakawa M, Suzuki T, Matsuda M, Fujii H, Rusyn I: Predictive power of biomarkers of oxidative stress and inflammation in patients with hepatitis C virus-associated hepatocellular carcinoma. Ann Surg Oncol 2007, 14:1182-1190.

25. Chang J, Kim NG, Piao Z, Park C, Park KS, Paik YK, Lee WJ, Kim BR, Kim H: Assessment of chromosomal losses and gains in hepatocellular carcinoma. Cancer Lett 2002, 182:193-202.

26. Moinzadeh P, Breuhahn K, Stutzer H, Schirmacher P: Chromosome alterations in human hepatocellular carcinomas correlate with aetiology and histological grade-results of an explorative CGH meta-analysis. $\mathrm{Br} J$ Cancer 2005, 92:935-941.

27. Thorgeirsson SS, Grisham JW: Molecular pathogenesis of human hepatocellular carcinoma. Nat Genet 2002, 31:339-346.

28. Homayounfar K, Gunawan B, Cameron S, Haller F, Baumhoer D, Uecker S, Sander B, Ramadori G, Lorf T, Fuzesi L: Pattern of chromosomal aberrations in primary liver cancers identified by comparative genomic hybridization. Hum Pathol 2009, 40:834-842.

29. Laurent-Puig $P$, Legoix $P$, Bluteau $O$, Belghiti J, Franco D, Binot F, Monges $G$ Thomas G, Bioulac-Sage P, Zucman-Rossi J: Genetic alterations associated with hepatocellular carcinomas define distinct pathways of hepatocarcinogenesis. Gastroenterology 2001, 120:1763-1773.

30. Nagai H, Pineau P, Tiollais P, Buendia MA, Dejean A: Comprehensive allelotyping of human hepatocellular carcinoma. Oncogene 1997, 14:2927-2933.

31. Wilkens L, Bredt M, Flemming P, Mengel M, Becker T, Klempnauer J, Kreipe $\mathrm{H}$ : Comparative genomic hybridization (CGH) and fluorescence in situ hybridization (FISH) in the diagnosis of hepatocellular carcinoma. J Hepatobiliary Pancreat Surg 2002, 9:304-311.

32. Wilkens L, Bredt M, Flemming P, Klempnauer J, Heinrich KH: Differentiation of multicentric origin from intra-organ metastatic spread of hepatocellular carcinomas by comparative genomic hybridization. $J$ Pathol 2000, 192:43-51.

33. Chen YJ, Yeh SH, Chen JT, Wu CC, Hsu MT, Tsai SF, Chen PJ, Lin CH: Chromosomal changes and clonality relationship between primary and recurrent hepatocellular carcinoma. Gastroenterology 2000, 119:431-440.

34. Edamoto Y, Hara A, Biernat W, Terracciano L, Cathomas G, Riehle HM, Matsuda M, Fujii H, Scoazec JY, Ohgaki H: Alterations of RB1, p53 and Wnt pathways in hepatocellular carcinomas associated with hepatitis $C$, hepatitis B and alcoholic liver cirrhosis. Int J Cancer 2003, 106:334-341.

35. Murakami $Y$, Hayashi $K$, Hirohashi S, Sekiya T: Aberrations of the tumor suppressor p53 and retinoblastoma genes in human hepatocellular carcinomas. Cancer Res 1991, 51:5520-5525. 
36. Liew CT, Li HM, Lo KW, Leow CK, Chan JY, Hin LY, Lau WY, Lai PB, Lim BK, Huang J, et al: High frequency of p16INK4A gene alterations in hepatocellular carcinoma. Oncogene 1999, 18:789-795.

37. De Souza AT, Hankins GR, Washington MK, Orton TC, Jirtle RL: M6P/IGF2R gene is mutated in human hepatocellular carcinomas with loss of heterozygosity. Nat Genet 1995, 11:447-449.

38. Oka Y, Waterland RA, Killian JK, Nolan CM, Jang HS, Tohara K, Sakaguchi S, Yao T, Iwashita A, Yata Y, et al: M6P/IGF2R tumor suppressor gene mutated in hepatocellular carcinomas in Japan. Hepatology 2002, 35:1153-1163.

39. Laurent-Puig P, Zucman-Rossi J: Genetics of hepatocellular tumors. Oncogene 2006, 25:3778-3786.

40. Hussain SP, Schwank J, Staib F, Wang XW, Harris CC: TP53 mutations and hepatocellular carcinoma: insights into the etiology and pathogenesis of liver cancer. Oncogene 2007, 26:2166-2176.

41. Wong CM, Fan ST, Ng IO: beta-Catenin mutation and overexpression in hepatocellular carcinoma: clinicopathologic and prognostic significance. Cancer 2001, 92:136-145.

42. Miyoshi Y, Iwao K, Nagasawa Y, Aihara T, Sasaki Y, Imaoka S, Murata M, Shimano T, Nakamura $Y$ : Activation of the beta-catenin gene in primary hepatocellular carcinomas by somatic alterations involving exon 3 . Cancer Res 1998, 58:2524-2527.

43. Hussain SP, Harris CC: p53 biological network: at the crossroads of the cellular-stress response pathway and molecular carcinogenesis. J Nippon Med Sch 2006, 73:54-64.

44. Aguilar F, Hussain SP, Cerutti P: Aflatoxin B1 induces the transversion of $\mathrm{G}->\mathrm{T}$ in codon 249 of the p53 tumor suppressor gene in human hepatocytes. Proc Natl Acad Sci USA 1993, 90:8586-8590.

45. Kirk GD, Lesi OA, Mendy M, Szymanska K, Whittle H, Goedert JJ, Hainaut P, Montesano R: 249(ser) TP53 mutation in plasma DNA, hepatitis B viral infection, and risk of hepatocellular carcinoma. Oncogene 2005, 24:5858-5867.

46. Wang XW, Forrester K, Yeh H, Feitelson MA, Gu JR, Harris CC: Hepatitis B virus $X$ protein inhibits p53 sequence-specific DNA binding, transcriptional activity, and association with transcription factor ERCC3. Proc Natl Acad Sci USA 1994, 91:2230-2234.

47. Sheen IS, Jeng KS, Wu JY: Is p53 gene mutation an indicatior of the biological behaviors of recurrence of hepatocellular carcinoma? World $J$ Gastroenterol 2003, 9:1202-1207.

48. Jeng KS, Sheen IS, Chen BF, Wu JY: Is the p53 gene mutation of prognostic value in hepatocellular carcinoma after resection? Arch Surg 2000, 135:1329-1333.

49. Woo HG, Wang XW, Budhu A, Kim YH, Kwon SM, Tang ZY, Sun Z, Harris CC, Thorgeirsson SS: Association of TP53 Mutations with Stem Cell-Like Gene Expression and Survival of Patients with Hepatocellular Carcinoma. Gastroenterology 2010.

50. Hong H, Takahashi K, Ichisaka T, Aoi T, Kanagawa O, Nakagawa M, Okita K, Yamanaka S: Suppression of induced pluripotent stem cell generation by the p53-p21 pathway. Nature 2009, 460:1132-1135.

51. Derynck R, Akhurst RJ, Balmain A: TGF-beta signaling in tumor suppression and cancer progression. Nat Genet 2001, 29:117-129.

52. Dennis PA, Rifkin DB: Cellular activation of latent transforming growth factor beta requires binding to the cation-independent mannose 6phosphate/insulin-like growth factor type II receptor. Proc Natl Acad Sci USA 1991, 88:580-584.

53. Breuhahn K, Vreden S, Haddad R, Beckebaum S, Stippel D, Flemming P, Nussbaum T, Caselmann WH, Haab BB, Schirmacher P: Molecular profiling of human hepatocellular carcinoma defines mutually exclusive interferon regulation and insulin-like growth factor II overexpression. Cancer Res 2004, 64:6058-6064.

54. El-Serag HB, Rudolph KL: Hepatocellular carcinoma: epidemiology and molecular carcinogenesis. Gastroenterology 2007, 132:2557-2576.

55. Tang Y, Kitisin K, Jogunoori W, Li C, Deng CX, Mueller SC, Ressom HW, Rashid A, He AR, Mendelson JS, et al: Progenitor/stem cells give rise to liver cancer due to aberrant TGF-beta and IL-6 signaling. Proc Natl Acad Sci USA 2008, 105:2445-2450.

56. Rebouissou S, Amessou M, Couchy G, Poussin K, Imbeaud S, Pilati C, Izard T, Balabaud C, Bioulac-Sage P, Zucman-Rossi J: Frequent in-frame somatic deletions activate gp130 in inflammatory hepatocellular tumours. Nature 2009, 457:200-204.

57. Chiba T, Zheng YW, Kita K, Yokosuka O, Saisho H, Onodera M, Miyoshi H, Nakano M, Zen $Y$, Nakanuma $Y$, et al: Enhanced self-renewal capability in hepatic stem/progenitor cells drives cancer initiation. Gastroenterology 2007, 133:937-950.

58. Clevers $\mathrm{H}$ : Wnt/beta-catenin signaling in development and disease. Cell 2006, 127:469-480.

59. Kikuchi A: Regulation of beta-catenin signaling in the Wnt pathway. Biochem Biophys Res Commun 2000, 268:243-248.

60. Yamashita T, Ji J, Budhu A, Forgues M, Yang W, Wang HY, Jia H, Ye Q, Qin LX, Wauthier E, et al: EpCAM-positive hepatocellular carcinoma cells are tumor-initiating cells with stem/progenitor cell features. Gastroenterology 2009, 136:1012-1024.

61. Cavard C, Colnot S, Audard V, Benhamouche S, Finzi L, Torre C, Grimber G, Godard C, Terris B, Perret C: Wnt/beta-catenin pathway in hepatocellular carcinoma pathogenesis and liver physiology. Future Oncol 2008, 4:647-660.

62. Chiba T, Kita K, Zheng YW, Yokosuka O, Saisho H, Iwama A, Nakauchi H, Taniguchi H: Side population purified from hepatocellular carcinoma cells harbors cancer stem cell-like properties. Hepatology 2006, 44:240-251.

63. Chan $\mathrm{KL}$, Guan $X Y, \mathrm{Ng}$ IO: High-throughput tissue microarray analysis of c-myc activation in chronic liver diseases and hepatocellular carcinoma. Hum Pathol 2004, 35:1324-1331.

64. Wilkens L, Flemming P, Gebel M, Bleck J, Terkamp C, Wingen L, Kreipe H, Schlegelberger B: Induction of aneuploidy by increasing chromosomal instability during dedifferentiation of hepatocellular carcinoma. Proc Natl Acad Sci USA 2004, 101:1309-1314.

65. Wu KJ, Grandori C, Amacker M, Simon-Vermot N, Polack A, Lingner J, laFavera R: Direct activation of TERT transcription by c-MYC. Nat Genet 1999, 21:220-224.

66. Chang TC, Yu D, Lee YS, Wentzel EA, Arking DE, West KM, Dang CV, Thomas-Tikhonenko A, Mendell JT: Widespread microRNA repression by Myc contributes to tumorigenesis. Nat Genet 2008, 40:43-50.

67. Bjerkvig R, Tysnes BB, Aboody KS, Najbauer J, Terzis AJ: Opinion: the origin of the cancer stem cell: current controversies and new insights. Nat Rev Cancer 2005, 5:899-904.

68. Hu TH, Huang CC, Lin PR, Chang HW, Ger LP, Lin YW, Changchien CS, Lee $\mathrm{CM}$, Tai MH: Expression and prognostic role of tumor suppressor gene PTEN/MMAC1/TEP1 in hepatocellular carcinoma. Cancer 2003, 97:1929-1940.

69. Blanco-Aparicio C, Renner O, Leal JF, Carnero A: PTEN, more than the AKT pathway. Carcinogenesis 2007, 28:1379-1386.

70. Nakanishi K, Sakamoto M, Yamasaki S, Todo S, Hirohashi S: Akt phosphorylation is a risk factor for early disease recurrence and poor prognosis in hepatocellular carcinoma. Cancer 2005, 103:307-312.

71. He XC, Yin T, Grindley JC, Tian Q, Sato T, Tao WA, Dirisina R, PorterWestpfahl KS, Hembree M, Johnson T, et al: PTEN-deficient intestinal stem cells initiate intestinal polyposis. Nat Genet 2007, 39:189-198.

72. Ji J, Wang XW: New kids on the block: Diagnostic and prognostic microRNAs in hepatocellular carcinoma. Cancer Biol Ther 2009, 8:1686-1693.

73. Ji J, Yamashita T, Budhu A, Forgues M, Jia HL, Li C, Deng C, Wauthier E, Reid LM, Ye QH, et al: Identification of microRNA-181 by genome-wide screening as a critical player in EpCAM-positive hepatic cancer stem cells. Hepatology 2009, 50:472-480.

74. Wang B, Hsu SH, Majumder S, Kutay H, Huang W, Jacob ST, Ghoshal K: TGFbeta-mediated upregulation of hepatic miR-181b promotes hepatocarcinogenesis by targeting TIMP3. Oncogene 2010, 29:1787-1797.

75. Ji J, Zhao L, Budhu A, Forgues M, Jia HL, Qin LX, Ye QH, Yu J, Shi X, Tang ZY, et al: Let-7g targets collagen type I alpha2 and inhibits cell migration in hepatocellular carcinoma. J Hepatol 2010, 52:690-697.

76. Ji J, Shi J, Budhu A, Yu Z, Forgues M, Roessler S, Ambs S, Chen Y, Meltzer PS, Croce CM, et al: MicroRNA expression, survival, and response to interferon in liver cancer. N Engl J Med 2009, 361:1437-1447.

77. Meng F, Henson R, Wehbe-Janek H, Ghoshal K, Jacob ST, Patel T: MicroRNA-21 regulates expression of the PTEN tumor suppressor gene in human hepatocellular cancer. Gastroenterology 2007, 133:647-658.

78. Jiang J, Gusev Y, Aderca I, Mettler TA, Nagorney DM, Brackett DJ, Roberts LR, Schmittgen TD: Association of MicroRNA expression in hepatocellular carcinomas with hepatitis infection, cirrhosis, and patient survival. Clin Cancer Res 2008, 14:419-427.

79. Varnholt $\mathrm{H}$ : The role of microRNAs in primary liver cancer. Ann Hepatol 2008, 7:104-113. 
80. Budhu A, Jia HL, Forgues M, Liu CG, Goldstein D, Lam A, Zanetti KA, Ye QH, Qin LX, Croce CM, et al: Identification of metastasis-related microRNAs in hepatocellular carcinoma. Hepatology 2008, 47:897-907.

81. Jones PA, Baylin SB: The fundamental role of epigenetic events in cancer. Nat Rev Genet 2002, 3:415-428.

82. Lehmann U, Wingen LU, Brakensiek K, Wedemeyer $H$, Becker T, Heim A, Metzig K, Hasemeier B, Kreipe $H$, Flemming P: Epigenetic defects of hepatocellular carcinoma are already found in non-neoplastic liver cells from patients with hereditary haemochromatosis. Hum Mol Genet 2007, 16:1335-1342.

83. Wong CM, Ng IO: Molecular pathogenesis of hepatocellular carcinoma. Liver Int 2008, 28:160-174

84. Sakai T, Toguchida J, Ohtani N, Yandell DW, Rapaport JM, Dryja TP: Allelespecific hypermethylation of the retinoblastoma tumor-suppressor gene. Am J Hum Genet 1991, 48:880-888.

85. Wang L, Wang WL, Zhang Y, Guo SP, Zhang J, Li QL: Epigenetic and genetic alterations of PTEN in hepatocellular carcinoma. Hepatol Res 2007, 37:389-396.

86. Datta J, Kutay H, Nasser MW, Nuovo GJ, Wang B, Majumder S, Liu CG, Volinia S, Croce CM, Schmittgen TD, et al: Methylation mediated silencing of MicroRNA-1 gene and its role in hepatocellular carcinogenesis. Cancer Res 2008, 68:5049-5058.

87. Furuta M, Kozaki Kl, Tanaka S, Arii S, Imoto I, Inazawa J: miR-124 and miR203 are epigenetically silenced tumor-suppressive microRNAs in hepatocellular carcinoma. Carcinogenesis 2010, 31:766-776.

88. Zhang YJ, Wu HC, Shen J, Ahsan H, Tsai WY, Yang HI, Wang LY, Chen SY, Chen CJ, Santella RM: Predicting hepatocellular carcinoma by detection of aberrant promoter methylation in serum DNA. Clin Cancer Res 2007, 13:2378-2384

89. Lee JS, Chu IS, Heo J, Calvisi DF, Sun Z, Roskams T, Durnez A, Demetris AJ, Thorgeirsson SS: Classification and prediction of survival in hepatocellular carcinoma by gene expression profiling. Hepatology 2004, 40:667-676.

90. Boyault S, Rickman DS, de Reynies A, Balabaud C, Rebouissou S, Jeannot E, Herault A, Saric J, Belghiti J, Franco D, et al: Transcriptome classification of $\mathrm{HCC}$ is related to gene alterations and to new therapeutic targets. Hepatology 2007, 45:42-52.

91. Yamashita T, Forgues M, Wang W, Kim JW, Ye Q, Jia H, Budhu A, Zanetti KA, Chen Y, Qin LX, et al: EpCAM and alpha-fetoprotein expression defines novel prognostic subtypes of hepatocellular carcinoma. Cancer Res 2008, 68:1451-1461.

92. Yeh SH, Chen PJ, Shau WY, Chen YW, Lee PH, Chen JT, Chen DS: Chromosomal allelic imbalance evolving from liver cirrhosis to hepatocellular carcinoma. Gastroenterology 2001, 121:699-709.

93. Aihara T, Noguchi S, Sasaki Y, Nakano H, Imaoka S: Clonal analysis of regenerative nodules in hepatitis $C$ virus-induced liver cirrhosis. Gastroenterology 1994, 107:1805-1811.

94. Yang XR, Xu Y, Yu B, Zhou J, Qiu SJ, Shi GM, Zhang BH, Wu WZ, Shi YH, Wu B, et al: High expression levels of putative hepatic stem/progenitor cell biomarkers related to tumour angiogenesis and poor prognosis of hepatocellular carcinoma. Gut 2010, 59:953-962.

95. Haruna Y, Saito K, Spaulding S, Nalesnik MA, Gerber MA: Identification of bipotential progenitor cells in human liver development. Hepatology 1996, 23:476-481.

96. Wu PC, Lai VC, Fang JW, Gerber MA, Lai CL, Lau JY: Hepatocellular carcinoma expressing both hepatocellular and biliary markers also expresses cytokeratin 14, a marker of bipotential progenitor cells. $J$ Hepatol 1999, 31:965-966.

97. Allen RA, Lisa JR: Combined liver cell and bile duct carcinoma. Am J Pathol 1949, 25:647-655.

98. Woo HG, Lee JH, Yoon JH, Kim CY, Lee HS, Jang JJ, Yi NJ, Suh KS, Lee KU, Park ES, et al: Identification of a cholangiocarcinoma-like gene expression trait in hepatocellular carcinoma. Cancer Res 2010, 70:3034-3041.

99. Fava G: Molecular mechanisms of cholangiocarcinoma. World J Gastrointest Pathophsiol 2010, 1:12-22.

100. Haswell-Elkins MR, Satarug S, Tsuda M, Mairiang E, Esumi H, Sithithaworn $P$, Mairiang $P$, Saitoh M, Yongvanit $P$, Elkins DB: Liver fluke infection and cholangiocarcinoma: model of endogenous nitric oxide and extragastric nitrosation in human carcinogenesis. Mutat Res 1994, 305:241-252.

101. Rosen CB, Nagorney DM, Wiesner RH, Coffey RJ Jr, LaRusso NF: Cholangiocarcinoma complicating primary sclerosing cholangitis. Ann Surg 1991, 213:21-25
102. Chen MF, Jan YY, Wang CS, Hwang TL, Jeng LB, Chen SC, Chen TJ: A reappraisal of cholangiocarcinoma in patient with hepatolithiasis. Cancer 1993, 71:2461-2465.

103. Jaiswal M, LaRusso NF, Burgart LJ, Gores GJ: Inflammatory cytokines induce DNA damage and inhibit DNA repair in cholangiocarcinoma cells by a nitric oxide-dependent mechanism. Cancer Res 2000, 60:184-190.

104. Sirica AE: Cholangiocarcinoma: molecular targeting strategies for chemoprevention and therapy. Hepatology 2005, 41:5-15.

105. Sell S, Dunsford HA: Evidence for the stem cell origin of hepatocellular carcinoma and cholangiocarcinoma. Am J Pathol 1989, 134:1347-1363.

106. Komuta M, Spee B, Vander BS, De VR, Verslype C, Aerts R, Yano H, Suzuki T, Matsuda M, Fujii H, et al: Clinicopathological study on cholangiolocellular carcinoma suggesting hepatic progenitor cell origin. Hepatology 2008, 47:1544-1556.

107. Roskams T: Liver stem cells and their implication in hepatocellular and cholangiocarcinoma. Oncogene 2006, 25:3818-3822.

108. Miller G, Socci ND, Dhall D, D'Angelica M, DeMatteo RP, Allen PJ, Singh B, Fong $Y$, Blumgart LH, Klimstra DS, et al: Genome wide analysis and clinical correlation of chromosomal and transcriptional mutations in cancers of the biliary tract. J Exp Clin Cancer Res 2009, 28:62.

109. Koo SH, Ihm CH, Kwon KC, Lee JS, Park JW, Kim JW: Microsatellite alterations in hepatocellular carcinoma and intrahepatic cholangiocarcinoma. Cancer Genet Cytogenet 2003, 146:139-144.

110. Ding SF, Delhanty JD, Bowles L, Dooley JS, Wood CB, Habib NA: Loss of constitutional heterozygosity on chromosomes 5 and 17 in cholangiocarcinoma. Br J Cancer 1993, 67:1007-1010.

111. Kang YK, Kim WH, Lee HW, Lee HK, Kim Yl: Mutation of p53 and K-ras, and loss of heterozygosity of APC in intrahepatic cholangiocarcinoma. Lab Invest 1999, 79:477-483

112. Kiba T, Tsuda H, Pairojkul C, Inoue S, Sugimura T, Hirohashi S: Mutations of the p53 tumor suppressor gene and the ras gene family in intrahepatic cholangiocellular carcinomas in Japan and Thailand. Mol Carcinog 1993, 8:312-318.

113. Qiu SJ, Ye SL, Wu ZQ, Tang ZY, Liu YK: The expression of the mdm2 gene may be related to the aberration of the $\mathrm{p} 53$ gene in human hepatocellular carcinoma. J Cancer Res Clin Oncol 1998, 124:253-258.

114. Tada M, Omata M, Ohto M: High incidence of ras gene mutation in intrahepatic cholangiocarcinoma. Cancer 1992, 69:1115-1118.

115. Furubo S, Harada K, Shimonishi T, Katayanagi K, Tsui W, Nakanuma Y: Protein expression and genetic alterations of p53 and ras in intrahepatic cholangiocarcinoma. Histopathology 1999, 35:230-240.

116. Horie S, Endo K, Kawasaki H, Terada T: Overexpression of MDM2 protein in intrahepatic cholangiocarcinoma: relationship with p53 overexpression, $\mathrm{Ki}$ 67 labeling, and clinicopathological features. Virchows Arch 2000, 437:25-30

117. Taniai M, Higuchi H, Burgart LJ, Gores GJ: p16INK4a promoter mutations are frequent in primary sclerosing cholangitis (PSC) and PSC-associated cholangiocarcinoma. Gastroenterology 2002, 123:1090-1098.

118. Lee S, Kim WH, Jung HY, Yang MH, Kang GH: Aberrant CpG island methylation of multiple genes in intrahepatic cholangiocarcinoma. Am J Pathol 2002, 161:1015-1022.

119. Tannapfel A, Sommerer F, Benicke M, Weinans L, Katalinic A, Geissler F, Uhlmann D, Hauss J, Wittekind C: Genetic and epigenetic alterations of the INK4a-ARF pathway in cholangiocarcinoma. J Pathol 2002, 197:624-631.

120. Petmitr S, Pinlaor S, Thousungnoen A, Karalak A, Migasena P: K-ras oncogene and p53 gene mutations in cholangiocarcinoma from Thai patients. Southeast Asian J Trop Med Public Health 1998, 29:71-75.

121. Momoi H, Itoh T, Nozaki Y, Arima Y, Okabe H, Satoh S, Toda Y, Sakai E, Nakagawara K, Flemming $P$, et al: Microsatellite instability and alternative genetic pathway in intrahepatic cholangiocarcinoma. J Hepatol 2001, 35:235-244.

122. Rashid A, Ueki T, Gao YT, Houlihan PS, Wallace C, Wang BS, Shen MC, Deng J, Hsing AW: K-ras mutation, p53 overexpression, and microsatellite instability in biliary tract cancers: a population-based study in China. Clin Cancer Res 2002, 8:3156-3163.

123. Berthiaume EP, Wands J: The molecular pathogenesis of cholangiocarcinoma. Semin Liver Dis 2004, 24:127-137.

124. Meng F, Henson R, Lang M, Wehbe H, Maheshwari S, Mendell JT, Jiang J, Schmittgen TD, Patel T: Involvement of human micro-RNA in growth and response to chemotherapy in human cholangiocarcinoma cell lines. Gastroenterology 2006, 130:2113-2129. 
125. Mott JL, Kobayashi S, Bronk SF, Gores GJ: mir-29 regulates Mcl-1 protein expression and apoptosis. Oncogene 2007, 26:6133-6140.

126. Poon RT, Fan ST, Lo CM, Liu CL, Wong J: Long-term survival and pattern of recurrence after resection of small hepatocellular carcinoma in patients with preserved liver function: implications for a strategy of salvage transplantation. Ann Surg 2002, 235:373-382.

127. Meza-Junco J, Montano-Loza AJ, Ma M, Wong W, Sawyer MB, Bain VG: Cholangiocarcinoma: has there been any progress? Can J Gastroenterol 2010, 24:52-57.

128. Gonzalez B, Denzel S, Mack B, Conrad M, Gires O: EpCAM is involved in maintenance of the murine embryonic stem cell phenotype. Stem Cells 2009, 27:1782-1791.

129. Yamashita T, Budhu A, Forgues M, Wang XW: Activation of hepatic stem cell marker EpCAM by Wnt-ß-catenin signaling in hepatocellular carcinoma. Cancer Research 2007, 67:10831-10839.

130. Ladeiro Y, Couchy G, Balabaud C, Bioulac-Sage P, Pelletier L, Rebouissou S, Zucman-Rossi J: MicroRNA profiling in hepatocellular tumors is associated with clinical features and oncogene/tumor suppressor gene mutations. Hepatology 2008, 47:1955-1963.

131. Chung GE, Yoon JH, Myung SJ, Lee JH, Lee SH, Lee SM, Kim SJ, Hwang SY, Lee HS, Kim CY: High expression of microRNA-15b predicts a low risk of tumor recurrence following curative resection of hepatocellular carcinoma. Oncol Rep 2010, 23:113-119.

132. Kota J, Chivukula RR, O'donnell KA, Wentzel EA, Montgomery CL, Hwang HW, Chang TC, Vivekanandan P, Torbenson M, Clark KR, et al: Therapeutic microRNA delivery suppresses tumorigenesis in a murine liver cancer model. Cell 2009, 137:1005-1017.

133. Maetzel D, Denzel S, Mack B, Canis M, Went P, Benk M, Kieu C, Papior P, Baeuerle $\mathrm{PA}$, Munz $\mathrm{M}$, et al: Nuclear signalling by tumour-associated antigen EpCAM. Nat Cell Biol 2009, 11:162-171.

134. Hay N: The Akt-mTOR tango and its relevance to cancer. Cancer Cell 2005, 8:179-183.

doi:10.1186/2045-3701-1-5

Cite this article as: Kumar et al:: Molecular carcinogenesis of hepatocellular carcinoma and intrahepatic cholangiocarcinoma: one step closer to personalized medicine? Cell \& Bioscience 2011 1:5.

\section{Submit your next manuscript to BioMed Central and take full advantage of:}

- Convenient online submission

- Thorough peer review

- No space constraints or color figure charges

- Immediate publication on acceptance

- Inclusion in PubMed, CAS, Scopus and Google Scholar

- Research which is freely available for redistribution

Submit your manuscript at www.biomedcentral.com/submit
Biomed Central 